\title{
SOB O SIGNO DA CRISE: ASCENSÃO E QUEDA DE RUBIÃO
}

\author{
Manoel Freire e Maria Clediane de Oliveira \\ Universidade do Estado do Rio Grande do Norte \\ Pau dos Ferros, RN, Brasil
}

\begin{abstract}
Resumo: Este artigo analisa alguns aspectos das relações sociais implicadas na configuração da trama do romance Quincas Borba, de Machado de Assis. Num ambiente de princípios frágeis e valores relativos, cuja ética se molda às conveniências do mais forte, o protagonista Rubião se apresenta sob o signo da crise. Ao sucumbir às armadilhas do casal Palha e às falsas lisonjas de um séquito de parasitas, Rubião vai gradualmente perdendo sua fortuna e, na mesma medida, a razão, de forma que logo chega à miséria e à loucura, retornando à sua Barbacena, onde morrerá como um pobre diabo. Através da trajetória do seu protagonista, Machado de Assis nos mostra que, numa sociedade movida pela cobiça e regida pela "lei do mais forte", a sobrevivência depende da esperteza de quem domina a ética dos vencedores.
\end{abstract}

Palavras-chave: literatura; sociedade; romance; crise.

\section{Under the sign of crisis: rise and fall of Rubião}

\begin{abstract}
The main aim of this article is to examine some aspects of the social relations involved in the plot of the novel Quincas Borba, by Machado de Assis. In an environment of fragile principles and relative values, in which ethics are shaped by conveniences of the strongest, the protagonist Rubião presents himself under the sign of crisis. By falling into Palha's trap and false flattery of a retinue of parasites, Rubião gradually loses his fortune, and to the same extent his reason, and ends up destitute and mad, returning to his native Barbacena, where he dies as a nobody. Through the trajectory of his protagonist, Machado de Assis demonstrates that in a society driven by greed and governed by the "survival of the fittest", survival depends on cleverness of those who dominate the ethics of the winners.
\end{abstract}

Keywords: literature; society; novel; crisis.

Este artigo apresenta uma discussão acerca das relações sociais figuradas no romance Quincas Borba, tendo como eixo condutor a personagem Rubião, protagonista da história. Este, ao receber uma herança do filósofo Quincas Borba, adentra o mundo capitalista e muda radicalmente seu modo de vida, na medida em que deixa o cotidiano pacato e monótono da província para viver na capital do Império, onde passa a frequentar festas e recepções nos grandes salões da alta sociedade. No entanto, a sua incapacidade para compreender os mecanismos que regem a sociedade o tornam presa fácil da intricada rede de interesses. Isso faz com que o protagonista entre em processo 
de irreversível decadência, o que desencadeia uma sucessão de crises que só termina com seu aniquilamento, ao morrer pobre, louco e abandonado, como um mendigo.

\section{De Barbacena ao Rio de Janeiro}

Ao deparar-se pela primeira vez com o romance Quincas Borba, o leitor logo supõe que está diante de uma narrativa sobre o personagem Quincas Borba, que conhecera nas Memórias póstumas de Brás Cubas. Entretanto, ao abrir o livro e iniciar a leitura, constata que o protagonista é Rubião, ex-professor da cidade de Barbacena que, de forma inesperada e "meio por acaso", recebe como herança a fortuna de Quincas Borba, de quem era amigo e enfermeiro. Esse acontecimento é determinante no romance, pois marca a súbita ascensão socioeconômica do protagonista e desencadeia uma mudança radical na sua vida, que a partir daí seguirá um curso que se desenrola sob o signo da crise.

Embora Rubião se mostre surpreso por ter sido nomeado herdeiro universal de Quincas Borba, percebe-se que a fortuna do amigo não lhe era indiferente, pois dela o ex-professor esperava receber alguma fatia, pequena que fosse. Conforme sugere o narrador, Rubião compreendia bem a conveniência da amizade com o excêntrico filósofo, haja vista a dedicação quase paternal a este, sobretudo nas crises mais agudas, o que significava mais do que um gesto humanitário: "Não tivesse a esperança de um legado, pequeno que fosse. Era impossível que não deixasse uma lembrança". ${ }^{1}$

Mas o interesse de Rubião pela herança de Quincas Borba era maior do que sugerem inicialmente essas frases, como o narrador nos mostra ao mencionar os planos que o protagonista fazia sobre como empregar o dinheiro. Inclusive temia que fosse provada a incapacidade mental do testador e por isso a justiça anulasse o testamento, considerando como certa a herança, portanto. Antes de tornar-se enfermeiro de Quincas Borba, Rubião já havia procurado outro meio de aproximar-se da fortuna do amigo, tentando casá-lo com sua irmã Piedade, esperança que morreu com o falecimento precoce desta. Daí que a sua reação, ao saber-se herdeiro universal de Quincas Borba (que não tinha parentes), tenha sido um misto de alegria e remorso, mais do que de

\footnotetext{
${ }^{1}$ ASSIS, Machado de. Quincas Borba. 13 ed. São Paulo: Ática, 1995. p. 23.
} 
surpresa. Ao morrer, Quincas Borba deixa toda a sua fortuna para Rubião, sendo posta no testamento apenas uma condição: "guardar o herdeiro consigo o pobre cachorro Quincas Borba", exigindo "que o tratasse como se fosse a ele próprio testador, nada poupando em seu benefício, resguardando-o de moléstias, de fugas, de roubo ou de morte que lhe quisessem dar por maldade; cuidar finalmente como se cão não fosse, mas pessoa humana."2 A obrigação de cuidar do cachorro imposta a Rubião como condição para a posse e o usufruto da herança tem função irônica importante no romance, particularmente sob dois aspectos: sugere que o herdeiro "carregará uma cruz" até o fim da vida, pois além exigir cuidados (a parte material da obrigação), a presença do animal é motivo constante de remorso da parte de Rubião (encargo de consciência); sugere também que Quincas Borba é um louco e que nada que ele diz merece crédito, inclusive seu testamento e sua caricata filosofia.

Logo na primeira página do romance o narrador já nos deixa a par das transformações que ocorrem na vida de Rubião depois que este recebe a herança e ingressa no mundo dos ricos, passando a viver o glamour das festas e salões da Corte. $\mathrm{O}$ parágrafo que abre o romance é revelador, mostrando que as mudanças não se restringem à vida material do protagonista:

Rubião fitava a enseada - eram oito horas da manhã. Quem o visse, com os polegares metidos no cordão do chambre, à janela de uma grande casa em Botafogo, cuidaria que ele admirava aquele pedaço de água quieta, mas, em verdade, vos digo que pensava em outra coisa. Cotejava o passado com o presente. Que era, há um ano? Professor. Que é agora? Capitalista. Olha para si, para as chinelas (umas chinelas de Túnis, que lhe deu recente amigo, Cristiano Palha), para a casa, para o jardim, para a enseada, para os morros e para o céu; e tudo, desde as chinelas até o céu, tudo entra na mesma sensação de propriedade. $^{3}$

O narrador não deixa dúvidas quanto às mudanças que o dinheiro opera na vida de Rubião, e ao mesmo tempo sugere uma reflexão sobre a transformação da personagem ao passar de uma condição a outra. Embora na descrição o protagonista aparente comtemplar a natureza, na verdade pensava nas transformações que ocorreram

\footnotetext{
${ }^{2}$ Idem, p. 26.

${ }^{3}$ Idem, p. 13 .
} 
na sua vida, possibilitando-lhe sair da humilde condição de professor primário em Barbacena para a de capitalista na Corte. Inicialmente o narrador nos traz uma visão exterior, ao descrever em poucas linhas a figura de Rubião, "com os polegares no cordão do chambre, à janela de uma grande casa de Botafogo", a contemplar a paisagem (a enseada) e a refletir sobre a sua nova condição. Mas sorrateiramente conduz o nosso olhar para o interior do protagonista, mostrando-nos que a mudança de condição também se opera no plano subjetivo da personagem. Enquanto contempla a si e a tudo em volta, incluindo o que lhe pertence e o que não lhe pertence (as chinelas, a casa, o jardim, os morros, e até o céu), "tudo, desde as chinelas até o céu, tudo entra na mesma sensação de propriedade", sentimento que orienta o comportamento de Rubião ao longo do romance.

Enquanto examina seu "novo mundo", Rubião não deixa de refletir, com a satisfação constrangida da vitória sem mérito, sobre o "acaso" que, muitas vezes, decide o destino dos homens, dando a uns a fortuna, a outros, a desgraça. Recorda com certo desconforto que poderia estar vivendo noutra situação (provavelmente, ainda mestreescola em Barbacena), caso tivesse realizado o casamento de sua irmã Piedade com Quincas Borba, como pretendera. Aqui parece que Rubião assimila o princípio geral do Humanitismo, expresso na redução irônica do aforismo "ao vencedor as batatas", ao demostrar-se satisfeito (embora com uma sombra de constrangimento) com a morte da irmã antes do possível casamento. "Vejam como Deus escreve direito por linhas tortas, pensa ele. Se mana Piedade tem casado com Quincas Borba, apenas me daria uma esperança colateral"; ou seja, nunca o suficiente para tirá-lo da humilde condição de mestre-escola em Barbacena. Mas, para sua felicidade, "Não casou; ambos morreram, e aqui está tudo comigo; de modo que o que parecia uma desgraça...".

As reticências deixadas estrategicamente pelo narrador sugerem que os desdobramentos da narrativa completarão o sentido da frase, que o leitor e o próprio Rubião vão encontrar no caricato Humanitismo, a excêntrica filosofia de Quincas Borba, "uma mescla bufa de pensamentos filosóficos", 5 que no texto machadiano

\footnotetext{
${ }^{4}$ Idem, p. 13.

5 SCARPELLI, Narrar para não morrer: Memórias póstumas de Brás Cubas. In: Personae - Grandes personagens da Literatura Brasileira. São Paulo: Editora SENAC, 2001. p. 45.
} 
funciona como sátira aos vários determinismos vigentes no século XIX. ${ }^{6}$ Em Quincas Borba a trajetória das principais personagens ilustra a doutrina do Humanitismo, sobretudo a vida de Rubião, que herda a fortuna do amigo filósofo mas não chega a compreender a sua doutrina, daí por que acaba por perder a batalha ao adentrar a selva regida pela lei do "mais forte".

Através da caricata doutrina de Quincas Borba o narrador machadiano satiriza as várias correntes de pensamento na filosofia e nas ciências (os vários determinismos) que surgiram na Europa e se difundiram pelo Ocidente ao longo do século XIX, inclusive no Brasil, e com termo "humanitismo" sugere uma tradução paródica da palavra "humanidade". Na luta de todos contra todos, os interesses e as realizações individuais servem como justificativa para quaisquer atitudes humanas, da mais nobre à mais torpe. Mesmo naquilo que se poderia considerar uma tragédia, o que prevalece é a satisfação das próprias necessidades, pois "não há morte, há vida, porque a supressão de uma é a condição da sobrevivência da outra". 7 Daí porque a morte de Piedade e de Quincas Borba é apresentada como um fato necessário à ascensão social de Rubião, justificando-se dessa forma a satisfação deste por ter sobrevivido aos dois e recebido a herança, tornando-se "o vencedor", a quem caberiam "as batatas". Cabe ressaltar, porém, que Rubião não recebe o prêmio sem algum remorso, o que põe em dúvida a validade dos princípios da filosofia do amigo defunto, bem como a validade do próprio testamento, já que se tratava de um documento assinado por um doente metal.

Quincas Borba explica as premissas de sua doutrina a Rubião por meio das mais variadas histórias. Um dos exemplos utilizados por ele para explicar o que significam a morte e a vida na concepção do Humanitismo é a morte da própria avó, atropelada por uma sege cujo condutor estava com muita fome e atrasado para o jantar. As expressões "tinha fome", e "precisa comer" são repetidas várias vezes, dando ênfase à ideia de que a necessidade de comer e de saciar seus desejos sobrepõe-se a quaisquer princípios, a anciã era apenas um obstáculo no caminho do condutor, que buscava a satisfação de suas necessidades para garantir a própria sobrevivência.

\footnotetext{
${ }^{6}$ Para uma discussão acerca do papel das ideias na obra de Machado de Assis, ver: SCHW ARZ, Roberto. Um mestre na periferia do capitalismo. São Paulo: Duas Cidades; Editora 34. 2000.

${ }^{7}$ ASSIS, Machado de. Quincas Borba, cit., p. 19.
} 
São várias as metáforas que sugerem a necessidade da vitória do "mais forte" como lei universal, mas a alegoria campo de batatas é a mais recorrente, inclusive repete-se nos últimos instantes vividos por Rubião, quando este protagoniza não o papel do vencedor, mas o do vencido. Assim demonstra Quincas Borba a excêntrica doutrina:

\begin{abstract}
Supõe tu um campo de batatas e duas tribos famintas. As batatas apenas chegam para alimentar uma das tribos, que assim adquire forças para transpor a montanha e ir à outra vertente, onde há batatas em abundância; mas, se as duas tribos dividirem em paz as batatas do campo, não chegam a nutrir-se suficientemente e morrem de inanição. A paz, nesse caso, é a destruição; a guerra é a conservação. Uma das tribos extermina a outra e recolhe os despojos. Daí a alegria da vitória, os hinos, aclamações, recompensas públicas e todos os demais efeitos das ações bélicas. ${ }^{8}$
\end{abstract}

Assim, viver na sociedade capitalista é participar de um campo de batalha, e na luta pela sobrevivência apenas os indivíduos "fortes" e aptos alcançam a vitória, ao passo que os "fracos" são derrotados e aniquilados. Embora sem compreender a metáfora, Rubião, ao confrontar o seu passado com o presente, coloca-se no lugar dos vencedores. Porém, como o próprio Quincas Borba dissera, o ex-professor era um "ignaro", incapaz de assimilar os princípios da singular filosofia, ignorando, assim, as armadilhas e o jogo de interesses que regem a sociedade.

Um episódio importante, cujos desdobramentos são decisivos para o desfecho do romance, é a primeira viagem de Rubião ao Rio de Janeiro após tornar-se herdeiro de Quincas Borba. Na estação de Vassouras encontra Cristiano Palha e a esposa Sofia, com quem passa a conversar durante a viagem e de quem se faz "amigo" logo no primeiro encontro. O casal percebe que, enquanto a maioria dos passageiros apresentava expressão "carrancuda" de aborrecimento, Rubião demonstrava estar calmo e satisfeito. $\mathrm{Na}$ medida em que o casal se aproxima do provinciano e vai obtendo informações importantes sobre a sua vida, começa a manifestar maior interesse pelo provinciano. Ao ouvir que Rubião poderá viajar para a Europa, "Os olhos de Palha brilharam instantaneamente"; já ao descobrir que a ida do ex-professor ao Rio de Janeiro tinha por

\footnotetext{
${ }^{8}$ Idem, p. 19.
} 
finalidade tratar de um inventário, "os olhos deste não brilhavam, refletiam profundamente", informa o narrador, ${ }^{9}$ sugerindo a cobiça de Cristiano Palha.

Portanto, o ambicioso casal percebe de imediato que está diante da possibilidade de "um grande negócio", e procura logo estreitar as relações, pois se tratava de alguém cuja amizade lhes poderia trazer grandes vantagens. A esse respeito Luiz Costa Lima afirma que "a diferença que de fato os separa concerne ao código de comunicação da sociedade. Rubião lhe é absolutamente alheio; Palha e Sofia já o dominam e põem para funcionar ali mesmo, perante e às expensas do mestre-escola" ${ }^{10}$ A incapacidade de Rubião para compreender a linguagem da sociedade em que iria ingressar é fator determinante para enredá-lo na teia intricada de um mundo em que viveria em estado de crises permanentes, haja vista sua incapacidade para assimilar as regras do "novo mundo" que passaria a habitar. Quanto a isso o narrador não deixa dúvidas: "Rubião metera-se num mato cerrado, onde lhe cantavam todos os passarinhos da fortuna; regalava-se ao falar da herança; confessou que não sabia ainda a soma, mas podia calcular por longe...". ${ }^{11}$

Ao chegar ao Rio de Janeiro provido de fortuna, mas desprovido da linguagem e dos códigos que regem a sociedade na qual entraria, Rubião torna-se presa fácil dos mas "aptos" e muitos passam a tirar proveito e vantagens de sua fortuna. Além do casal Palha e Sofia, muitos outros personagens se aproximam do milionário, formando um séquito de parasitas, cada um com seus interesses particulares em relação à fortuna de Rubião, que ingenuamente acredita nas suas "boas intenções" e vai-se enredando nas suas armadilhas. A figura do parasita habita com frequência as páginas de Machado de Assis e apresenta diferentes tipos. Em uma crônica de 1859, denominada O parasita, o narrador machadiano fala de certo tipo de erva que deixa a terra em busca de altas árvores para se enroscar. Em seguida, afirma que assim como ocorre com as plantas, a sociedade também possui os mais diversos tipos de parasitas, "uma longa e curiosa

\footnotetext{
${ }^{9}$ Idem, p. 32 e p. 34.

${ }^{10}$ LIMA, Luiz Costa. Dispersa demanda: ensaios sobre literatura e teoria. Rio de Janeiro: Francisco Alves, 1981. p. 78.

${ }^{11}$ ASSIS, Machado de. Quincas Borba, cit., p. 34.
} 
família", sendo os mais importantes os "parasitas sociais". ${ }^{12}$ Em Quincas Borba, muitos frequentadores da casa de Rubião, como Freitas e Camacho, entre outros, assemelhamse aos tipos de parasita descritos na crônica.

Freitas é o típico "parasita de mesa", "elogiava tudo, saudava cada prato e cada vinho com uma frase particular, delicada, e saia de lá com as algibeiras cheias de charuto, provando, assim, que os preferia a quaisquer outros". ${ }^{13}$ Assíduo frequentador da casa de Rubião, lá almoçava e jantava, sempre a bajular a e a fazer duvidosos elogios, exaltando as qualidades dos pertences de Rubião e sugerindo que todos os objetos de propriedade deste eram superiores, desde as simples rosas do jardim até os móveis, as bebidas, os cálices; nada escapava à sua observação. Rubião evidentemente gostava de ser elogiado, e acreditava na sinceridade dos elogios, o que não passava despercebido ao astucioso parasita, que assim "alimentava a vaidade daquele que o alimentava materialmente". ${ }^{14}$ Crente na boa fé dos "amigos", o simplório milionário não consegue perceber os interesses que estavam por trás de cada gesto, tanto que ajuda ao Freitas com as suas despesas, quando este se encontra enfermo, chegando inclusive a custear o seu velório.

Após algum tempo no Rio de Janeiro, Rubião torna-se figura muito conhecida, de modo que as pessoas que passam a frequentar sua casa são cada vez mais numerosas. Aos poucos, a presença de Rubião torna-se desnecessária aos que frequentavam sua residência, e as refeições eram servidas mesmo na sua ausência, de tal modo ele havia perdido o controle sobre sua própria casa. Seus "amigos" utilizavam os objetos, entravam no gabinete, fumavam os charutos, tomavam posse de tudo que estava ao alcance, e tal promiscuidade se dava entre a ignorância e a complacência do protagonista. Como não há riqueza infinita, a crise era inevitável na residência de Rubião, e não tardaria que ele tivesse que trocar a opulência do palacete de Botafogo pela pobreza de uma "casinha" na rua do Príncipe. Curiosamente, mais do que o próprio Rubião, que a essa altura caminhava para o abismo da loucura e "adotou a mudança sem desgosto", os parasitas sofreram forte abalo com a mudança:

\footnotetext{
${ }^{12}$ ASSIS, Machado de. Melhores crônicas. Direção de Edla Van Steen; seleção de Salete Almeida Cara. 2. ed. São Paulo: Global, 2005. p. 25.

${ }^{13}$ ASSIS, Machado de. Quincas Borba, cit., p. 38.

${ }^{14}$ XAVIER, T. M. Verso e reverso do favor no romance de Machado de Assis. Viçosa: UFV, 1994. p. 31.
} 
[...] receberam a notícia da mudança como um decreto de exílio. Tudo na antiga habitação fazia parte deles, o jardim, a grade, os canteiros, os degraus de pedra, a enseada. Traziam tudo de cor. Era entrar, pendurar o chapéu, e ir esperar na sala. Tinham perdido a noção da casa alheia e do obséquio recebido. Depois, a vizinhança. ${ }^{15}$

Nota-se, portanto, que os comensais entravam e saiam da casa como se fossem os verdadeiros donos, explorando até onde podiam os bens de Rubião. Se a princípio havia rivalidade entre eles, depois de certo tempo estavam unidos por um interesse comum, usufruir o que ainda restava da antiga opulência. É nesse ambiente repleto de parasitas de toda espécie que a fortuna vai se exaurindo, entra em irreversível decadência, e Rubião desaba numa crise que se consumaria com a pobreza e a loucura. Marta de Senna comenta a trajetória do ex-professor da seguinte forma:

Rubião é o mais nítido exemplo do mecanismo de devoração do homem pelo homem, instrumento da ambição econômica da sociedade urbana de Palhas e Sofias, Camachos e Freitas. Tal qual os fracos e puros, é manipulado como uma coisa, exatamente por uma galeria de personagens terríveis, todos homens de corte burguês impecável, perfeitamente entrosados nos mores de sua classe e de seu espaço experiencial. ${ }^{16}$

A vida de Rubião depois que se torna capitalista nos permite compreender como se constituíam as relações sociais no Segundo Império, durante o qual os interesses pessoais sobrepunham-se a todos os valores e princípios, sendo constante o sistema de exploração em que os próprios indivíduos enxergam na figura do outro a possibilidade de obter vantagens financeiras. Cristiano Palha, figura exemplar do arrivista, é o principal responsável pela derrocada de Rubião, através de uma sociedade em que passa a gerir o capital do provinciano, aproveitando-se da boa fé e da ignorância deste, que por sua vez acreditava nas "boas intenções" e na generosidade do amigo, disfarçadas nas artimanhas sedutoras de Sofia.

\footnotetext{
${ }^{15}$ ASSIS, Machado de. Quincas Borba, cit., p. 183.

${ }^{16}$ SENNA, Marta de. O olhar oblíquo do bruxo: ensaios em torno de Machado de Assis. Rio de Janeiro: Nova Fronteira, 1998. p. 87.
} 
O comerciante utilizava sua esposa como um troféu, expondo-a para que todos pudessem vê-la e contemplá-la, e para isso comprava roupas adequadas para realçar a beleza do seu corpo e assim provocar o desejo dos homens - dos próprios amigos: "Tinha essa vaidade singular; decotava a mulher sempre que podia, e até onde podia, para mostrar aos outros as suas venturas particulares". ${ }^{17}$ Esta singularidade de Cristiano Palha vai ao encontro da vaidade de Sofia, cuja atitude o narrador apresenta com certa dose de ironia: "E façamos aqui justiça à nossa dama. A princípio, cedeu sem vontade aos desejos do marido; mas tais foram as admirações colhidas, e a tal ponto o uso acomoda a gente às circunstâncias, que ela acabou gostando de ser vista, muito vista, para recreio e estímulo dos outros". ${ }^{18}$ Fato decisivo para a concretização dos planos ambiciosos do casal é a paixão de Rubião por Sofia, que se esmera nas artimanhas para manter sob sua influência o capitalista, cujos desejos são aguçados pela dama, mas nunca satisfeitos, o que o mantém em permanente vulnerabilidade.

É interessante observar o comportamento de Sofia em relação à "paixão" de Rubião, pois ela não demonstra estar interessada nele, mas para não desenganá-lo completamente acaba alimentando suas esperanças, a ponto de o leitor imaginar, a princípio, na concretização do triângulo amoroso. Em certas ocasiões, todos os gestos de Sofia são cuidadosamente estudados, como sugere o narrador: "A boca parece mais fresca. Ombros, mãos, braços, são melhores, e ela ainda os faz ótimos por meio de atitudes e gestos escolhidos". ${ }^{19}$ Consciente de seus dotes e de sua beleza física, Sofia utiliza-os para manter acesa a chama do desejo em Rubião, e com isso recebe presentes caros e usufrui da sua fortuna, juntamente com o marido, que conhece bem as armas poderosas da esposa e delas sabe tirar proveito.

Há um episódio do romance em que Rubião declara seu amor a Sofia. Esta, por sua vez, surpreende-se com a ousadia do amigo e procura encontrar uma forma de contê-lo, porém sem que ele se irritasse a ponto de afastar-se de sua casa, o que faria com que ela e o marido perdessem a vantajosa amizade. Face a esse dilema, a própria Sofia relata ao marido a declaração que ouviu de Rubião e lhe pede que interrompa as

\footnotetext{
${ }^{17}$ ASSIS, Machado de. Quincas Borba, cit., p. 45.

${ }^{18}$ Idem, p. 45.

${ }^{19}$ Ibidem.
} 
relações com o ex-professor, porém reconhece que a situação é delicada: "confessar que entendia, e não despedi-lo de casa, eis aí o ponto melindroso". ${ }^{20}$ Isso nos leva a entender que o interesse de Sofia era somente seduzi-lo para obter cada vez mais vantagens, mas nada que pudesse chegar a uma traição. Diante da coragem de Rubião em se declarar, Sofia temia que os atos deste excedessem os limites da discrição a ponto de despertar a opinião pública e manchar sua reputação, já que estaria admitindo em sua casa a presença de um suposto amante, daí insinuar que o esposo deveria romper a amizade e encerrar a sociedade. Palha, por sua vez, acaba convencendo a mulher de que não é conveniente terminar uma relação tão vantajosa para o casal.

Rubião acredita que Palha está fazendo seus negócios renderem, deposita toda confiança no sócio e não consegue perceber o jogo de interesses ocultos que há por trás da ação deste. Através da fortuna de Rubião, Palha e Sofia conseguem realizar seus intentos: entram para o mundo dos ricos e conquistam o reconhecimento da alta sociedade. Daí em diante Rubião já não tem utilidade para eles, que passam a tratá-lo com frieza e indiferença, buscando distanciar-se dele e procurando romper definitivamente o vínculo que haviam estabelecido. $\mathrm{O}$ ganancioso Cristiano Palha propõe logo encerrar a sociedade, usando como pretexto um convite que teria recebido para ocupar a gerência de um banco.

Se na vida do casal Palha as vantagens e os lucros estavam em constante crescimento, na de Rubião as coisas trilhavam caminho inverso. Sem recursos, o herdeiro de Quincas Borba vê-se sozinho e abandonado por todos que antes o cortejavam, e começa a manifestar a loucura, até então latente, afundando no abismo de uma crise que o levaria ao fim. As constantes crises e delírios de Rubião nos permitem compreender os interesses que permeiam a sociedade, bem como a sua relação com o Humanitismo, doutrina para a qual a vida é um campo de batalha onde só os mais fortes sobrevivem, como anunciara Quincas Borba. Quando se torna rico e passa a frequentar os grandes salões da Corte, Rubião parece entender que o mundo de aparências e o dinheiro são os mecanismos que movimentam aquele ambiente, haja vista as mudanças que se operam na sua vida (a substituição, ainda que a contragosto, do antigo criado por um estrangeiro é um dado sintomático). No entanto, não consegue perceber que ele

\footnotetext{
${ }^{20}$ Idem, p. 49.
} 
próprio se tornara vítima desse jogo, em que somente os mais "espertos" podem sair como vencedores, como é o caso dos parasitas que o rodeavam, sobretudo Palha e Sofia, que estavam à frente de todos.

Quando os "amigos" de Rubião começam a perceber o seu estado de saúde, que se agrava após sucessivas crises, questionam o casal Palha quanto às providências a tomar, ponto crucial para vermos como o egoísmo e a hipocrisia prevalecem, e o quanto o homem é tratado como objeto. Exemplo disso pode-se verificar nos trechos a seguir, em que o narrador expressa a reação de Palha (fazendo falar a personagem) em relação ao estado mental e financeiro de Rubião:

Era rico - mas gastador. Conhecemo-lo quando veio de Minas, e fomos, por assim dizer, o seu guia no Rio de Janeiro, aonde não voltara desde longos anos. Bom homem. Sempre com luxo, lembrase? Mas, não há riqueza inesgotável, quando se entra pelo capital; foi o que ele fez. Hoje creio que tenha pouco....

Aqui o narrador, usando o discurso direto, apresenta um pequeno relato, mais ou menos objetivo, do que diz Cristiano Palha a Teófilo sobre o sócio, quando este chegou ao Rio de Janeiro. Mais adiante, ao sondar o interior da personagem, adota o discurso indireto livre e apresenta ao leitor o que pensava Cristiano Palha sobre a desgraça de Rubião: "Era uma atrapalhação ter de cuidar do outro, de o acompanhar e, provavelmente, de recolher e gerir algum resto de dinheiro que ainda houvesse, fazendo-se curador como dissera o doutor Teófilo. Um aborrecimento de todos os diabos". ${ }^{22}$ Fica evidente, portanto, que Palha procura isentar-se de qualquer responsabilidade pela decadência de Rubião, atribuindo a sua desgraça à vida de ostentação e luxo em que teria esbanjado a herança que recebera, sendo que, na verdade, ele e a esposa foram os principais responsáveis pela miséria de Rubião, que se tornara, depois de pobre, um estorvo, um aborrecimento que Palha não queria suportar.

Fato que merece atenção é que, em meio ao mar de hipocrisia e ambições mesquinhas em que os personagens de Quincas Borba estão mergulhados, há uma

\footnotetext{
${ }^{21}$ Idem, p. 176.

${ }^{22}$ Idem, p. 182.
} 
figura que demonstra preocupação com o estado de Rubião, agindo sem qualquer interesse oculto ou dissimulado, movida por princípios humanitários. Trata-se de Dona Fernanda, que insiste em que se deve (sobretudo o casal Palha) prestar assistência ao exprofessor. E é justamente essa insistência de pessoas do seu mesmo nível social que faz o casal Palha tomar alguma iniciativa, pois ele se preocupava com o que os outros poderiam pensar a seu respeito, como observa Alfredo Bosi, ao afirmar que Sofia "precisa aparentar 'bom-tom' junto à amiga prestigiosa, esposa de um deputado, quase ministro e futuro presidente de província". ${ }^{23}$ Como "nova rica", Sofia não pode descartar publicamente certas formas de comportamento. Assim, durante todo o tempo predomina em Sofia a preocupação com as aparências, com a imagem que deveria apresentar para a sociedade, tanto que ao sair da casa de Rubião (agora um casebre num bairro pobre e distante) tem o cuidado de olhar se havia alguém ao entorno, para evitar o vexame de ser vista em um local pobre e sujo: "Sofia, antes de pôr o pé na rua, olhou para um e outro lado, espreitando se vinha alguém; felizmente, a rua estava deserta. Ao ver-se livre da pocilga, Sofia readquiriu o uso das boas palavras". ${ }^{24}$

Os delírios de Rubião tornam-se cada vez mais frequentes e prolongados, a ponto de este mandar buscar diretamente da França os bustos de mármore dos dois Napoleões, chegando a se identificar com um deles. Somente após muito tempo é que Palha toma algumas providências, primeiro colocando-o em uma casinha simples e afastada, juntamente com o cachorro, e, em seguida, internando-o em uma casa de saúde. Decorridos alguns dias, Rubião foge da clínica e reaparece em Barbacena, a mesma cidade de onde saíra ao receber a herança, e lá ocorre sua morte, que o narrador nos mostra numa cena mista de tragédia e comédia:

Poucos dias depois morreu... Não morreu súdito nem vencido. Antes de principiar a agonia, que foi curta, pôs a coroa na cabeça uma coroa que não era, ao menos, um chapéu velho ou uma bacia, onde os espectadores palpassem a ilusão. Não, senhor; ele pegou em nada, levantou nada e cingiu nada; só ele via a insígnia imperial, pesada de ouro, rútila de brilhantes e outras pedras preciosas. $\mathrm{O}$ esforço que fizera para erguer meio corpo não durou muito; o corpo caiu outra vez; o rosto conservou porventura uma expressão gloriosa.

\footnotetext{
${ }^{23}$ BOSI, Alfredo. Machado de Assis - o enigma do olhar. 4. ed. São Paulo: Martins Fontes, 2007. p. 65.

${ }^{24}$ ASSIS, Machado de. Quincas Borba, cit., p. 208.
} 
- Guardem a minha coroa - murmurou. - Ao vencedor...

A cara ficou séria, porque a morte é séria; dois minutos de agonia, um trejeito horrível, e estava assinada a abdicação. ${ }^{25}$

Esse trágico fim nos remete ao início do romance, ao momento em que Quincas Borba, já demente, chama Rubião de ignaro: "a nossa intimidade permitia-me dizer palavra mais crua, mas faço-lhe esta concessão, que é a última. Ignaro!"26 Portanto, para Quincas Borba já era evidente a ignorância de Rubião face aos mecanismos de funcionamento da sociedade, traços que o fizeram presa fácil da ambição e da ganância de indivíduos sedentos de poder e riqueza a qualquer custo. A autocoroação de Rubião também é muito representativa e demonstra um dos pontos cruciais da obra machadiana: a relação entre o ser e o parecer, entre a realidade e as aparências, pois assim como a grande maioria das personagens, que age movida por interesses mesquinhos, de forma dissimulada, desde que chega ao Rio de Janeiro Rubião passa a viver conforme a necessidade das aparências, tanto que em seus últimos instantes de loucura acredita ser Napoleão III, colocando sobre a cabeça uma coroa que, na verdade, não passava de simples ilusão, ou ainda uma forma de fugir da realidade e evitar as dores, tal qual a ideia de um "mundo sem dor", fantasia do alienado Quincas Borba.

Ironicamente, Rubião repete seguidas vezes o aforismo "Ao vencedor, as batatas!", expressão síntese da caricata filosofia de Quincas Borba, que de certa forma traduz a natureza das relações na sociedade figurada no romance, bem como a sua própria trajetória. Considerando que Machado de Assis procura, em sua literatura, desnudar a hipocrisia da sociedade que ele tão bem conhecia, permitindo-nos visualizar a imagem do contexto social e cultural brasileiro de seu tempo, não é descabido ver em Rubião a representação alegórica de uma nação cujo trajeto sempre fora marcado por uma sucessão de crises. A esse respeito vale considerar a observação de John Gledson, que afirma:

\footnotetext{
${ }^{25}$ Idem, p. 214.

${ }^{26}$ Idem, p. 23.
} 
Ele pretendia que seu personagem retratasse, através de seu inconsciente e de sua incipiente loucura, os conflitos não apenas do provinciano que enfrenta uma sociedade metropolitana, despojado de armas, mas cheio de dinheiro e com uma filosofia louca, mas os conflitos com os quais estava aturdida a sociedade brasileira, mesmo em níveis dos quais essa sociedade não poderia ter inteira consciência. ${ }^{27}$

Gledson sugere que Rubião representa não apenas uma classe social, mas toda a nação brasileira, mostrando, através da vida deste personagem, uma alegoria do próprio Império, com os conflitos e dilemas que a sociedade brasileira desse período vivenciava e dos quais não tinha plena consciência. Assim, a pacata cidade de Barbacena representaria o Brasil conservador, e o Rio de Janeiro, a porção do país que se modernizava, conflito que estaria, segundo o crítico, representado na figura de Rubião, cuja loucura corresponderia à crise de identidade da nação face ao conflito entre o arcaico e o moderno.

Independentemente dos fundamentos e do alcance da interpretação de Gledson, é certo que Rubião não assimila os princípios da bizarra filosofia, como também não chega a compreender as regras do jogo social de que passa a fazer parte, nem se adapta plenamente à vida de milionário na corte, onde vive em permanente crise, inclusive de identidade. Ironicamente, os postulados do "Humanitismo" se cumprem na trajetória de Rubião e concretizam-se na sua relação com os outros indivíduos que o cercam. Segundo a doutrina, sobrevivem os mais fortes e capazes (uma espécie de darwinismo social), de modo que é essa luta pela sobrevivência que garante a conservação da espécie, sendo os fracos derrotados e eliminados da batalha. Aplicando isso ao percurso realizado por Rubião, nota-se que o seu fim trágico representa o destino dos derrotados, dos que não sabem (ou não souberam) compreender os mecanismos que regem uma sociedade orientada por valores inautênticos (cobiça, vaidade, hipocrisia), ou seja, por antivalores, daí o seu aniquilamento, em contraste com a ascensão de Palha e Sofia.

É importante destacar que Rubião não é o único personagem machadiano que não tem um final feliz após receber uma grande fortuna, ou seja, ao tornar-se rico sem esforço ou trabalho. Algo parecido ocorre com Helena, do romance homônimo, que

\footnotetext{
${ }^{27}$ GLEDSON, John. Machado de Assis - ficção e história. 2 ed. Ver. São Paulo: Paz e Terra, 2003. p. 96.
} 
mesmo sendo herdeira e recebendo amor da família do conselheiro Vale não consegue livrar-se do remorso e acaba morrendo. Em obras anteriores a Quincas Borba podemos acompanhar a trajetória de personagens economicamente privilegiados que levaram uma vida fútil e vazia. Em relação a isso, Xavier $^{28}$ observa que a esses personagens não é dado "alcançar um fim venturoso, parecendo ser propósito do autor a concretização daquela máxima popular: 'dinheiro não traz felicidade'. Assim, não há herói e heroína ditosos, após terem sido agraciados com algum patrimônio". É assim que se dá com Félix, de Ressurreição, que termina infeliz e solitário; com Jorge, de A mão e a luva, que é rejeitado por sua pretendente Guiomar e se torna um fracassado; com Brás Cubas, de Memórias póstumas..., que nada consegue realizar, concluindo ironicamente sua autobiografia com um capítulo de negativas.

\section{Referências:}

ASSIS. Machado de. Quincas Borba. 13. ed. São Paulo: Ática, 1995.

Melhores crônicas. Direção de Edla Van Steen; seleção de Salete Almeida Cara. 2. ed. São Paulo: Global, 2005.

BOSI, Alfredo. Machado de Assis - o enigma do olhar. 4. ed. São Paulo: Martins Fontes, 2007.

GLEDSON, John. Machado de Assis - ficção e história. 2 ed. Ver. São Paulo: Paz e Terra, 2003.

LIMA, Luiz Costa. Dispersa demanda: ensaios sobre literatura e teoria. Rio de Janeiro: Francisco Alves, 1981.

MAGALHÃES JUNIOR, Raimundo. Vida e obra de Machado de Assis, v. 2: ascensão. Rio de Janeiro: Record, 2008.

SCARPELLI, M. F. Narrar para não morrer: Memórias póstumas de Brás Cubas. In: Personae - Grandes personagens da Literatura Brasileira. São Paulo: Editora SENAC, 2001.

SENNA, Marta de. O olhar oblíquo do bruxo: ensaios em torno de Machado de Assis. Rio de Janeiro: Nova Fronteira, 1998.

${ }^{28}$ XAVIER, T. M. Verso e reverso do favor no romance de Machado de Assis, cit., p. 107. 
SCHWARZ, Roberto. Um mestre na periferia do capitalismo. São Paulo: Duas Cidades. Ed. 34. 2000.

XAVIER, T. M. Verso e reverso do favor no romance de Machado de Assis. Viçosa: UFV, 1994.

Manoel Freire é professor de Literatura Brasileira e pesquisador na Universidade do Estado do Rio Grande do Norte. É autor de alguns artigos e do livro Revolta $e$ melancolia: uma leitura da obra de Lima Barreto (no prelo). E-mail: <manoelfrr@gmail.com>.

Maria Clediane de Oliveira é aluna do Programa de Pós-graduação em Letras (Mestrado) pela Universidade do Estado do Rio Grande do Norte. É autora de alguns trabalhos sobre Machado de Assis, publicados em anais de eventos. E-mail: <cledianeoliveira@hotmail.com>.

Recebido: 15.09.2013

Aprovado: 18.11.2013 